\title{
PENGARUH METODE FORCE MOLTING YANG BERBEDA TERHADAP RONTOK BULU AYAM PETELUR AFKIR
}

\author{
Mohammad Nurdiana Fitroh ${ }^{1}$, Muh. Amrullah Pagala ${ }^{2}$ Hamdan Has \\ ${ }^{1)}$ Jurusan Produksi Ternak Fakultas Peternakan UHO \\ ${ }^{2)}$ Staf Pengajar Jurusan Produksi Ternak Fakultas Peternakan UHO \\ e-mail: amroe74@gmail.com
}

\begin{abstract}
Abstrak
Penelitian ini bertujuan untuk mengetahui pengaruh metode force molting berbeda terhadap rontok bulu ayam ras petelur pada masa akhir produksi telur (afkir). Sebanyak 18 ekor ayam petelur strain Lohman Brown, daun lamtoro, ransum basal, dedak padi digunakan sebagai materi penelitian. Rancangan yang digunakan adalah rancangan acak lengkap 3 perlakuan dan 6 ulangan, perlakuan yang digunakan adalah $\mathrm{P} 0=$ Pembatasan pakan dan pemuasaan, $\mathrm{P} 1=$ Pemuasaan dan penambahan daun lamtoro $20 \%, \mathrm{P} 2=$ Pemuasaan dan pemberian dedak padi. Perlakuan yang berpengaruh nyata dilanjutkan dengan uji jarak berganda Duncan. Variable yang diamati adalah jumlah rontok bulu leher, bulu punggung, bulu sayap, bulu ekor dan bulu dada. Hasil penelitian menunjukkan: Perlakuan force moting berbeda pada ayam petelur berpengaruh nyata $(\mathrm{p}<0.05)$ pada jumlah rontok bulu leher dan bulu dada tetapi tidak berpengaruh nyata $(p>0.05)$ pada jumlah rontok bulu punggung, bulu sayap, bulu ekor, selisih bobot badan dan lama masa berhenti bertelur. Kesimpulan dari penelitian ini yaitu perlakuan force molting dengan penambahan daun lamtoro menunjukkan hasil yang lebih baik.
\end{abstract}

Kata Kunci: Ayam Petelur Afkir, Rontok Bulu

\begin{abstract}
This study was aimed to determine the effect diference force molting eightten laying hens strain Lohman Brown, lamtoro leaf, feed, and rice bran were used as research material. Research design was used completly randomized design with 3 treatments and 6 replications, the parameters were total feather molt. The treatment that significantly followed by Duncan's multiple range test. The results showed that different force molting method in laying hens significant effect $(P<0.05)$ in total necle and chest feather molt but not significant $(p>0.05)$ in thetotal wing, and trail feather molt, body weight difference and the stop laying period. The conclusion was treatment with the addition lamtoro leave show better results.
\end{abstract}

Keywords: Force molting, culled hen. 


\section{PENDAHULUAN}

Unggas memiliki kecenderungan untuk menggugurkan bulu setiap tahunnya. Dalam kondisi normal perontokan bulu yang terjadi lebih awal menandakan bahwa ayam tersebut sebagai ayam petelur yang buruk demikian pula sebaliknya (Esminger, 1990).

Molting adalah peristiwa fisiologi pada unggas yang dipengaruhi oleh perubahan kadar hormon tiroid (Kuenzel, 2003). Proses molting pada ayam secara alami berlangsung selama kurang lebih empat bulan (Walbert, 2004). Jika dirangsang proses molting bisa berlangsung kurang lebih 5-9 minggu (Berry, 2003). Setelah molting akan terjadi peningkatan produksi telur, disebabkan adanya perbaikan fungsi ovarium oleh sel atau jaringan baru, (Barua et, al., 2001). Razak (2010) melaporkan bahwa terjadi peningkatan telur yang sangat signifikan pada ayam petelur afkir setelah dilakukan program molting menggunakan metode pemuasaan atau pembatasan pakan, rataan produksi telur yang paling tinggi ialah sebesar $68.20 \% \mathrm{HD}$.

Rontok bulu di pengaruhi oleh hormon prolaktin, gonadotropin, tiroksin, dan hormon steroid ovarium (Berry, 2003). Rontok secara alami terjadi pada akhir periode bertelur yang disebabkan tingginya hormon prolaktin pada tubuh ayam. Proses rontok pada ayam terjadi terjadi dengan pola tertentu. Rontok tubuh terjadi terlebih dahulu sebelum rontok sayap. Rontok tubuh terjadi dengan urutan rontoknya bulu kepala, leher, dada, pungung, sayap, dan ekor.
Rontok sayap tidak terjadi secara bersamaan. Bulu yang pertama kali rontok adalah bulu primer yang berdekatan dengan bulu aksial. Selanjutnya bulu rontok sesuai dengan urutannya (Suprijatna et, al. 2005).

Rontok secara alami berlangsung selama kurang lebih 4 bulan (Darmana dan Sitanggang (2005). Untuk mempercepat periode molting dapat dilakukan dengan cara rontok paksa (force molting). Rontok bulu paksa merupakan metode untuk mempercepat periode molting dengan prosedur tertentu sehingga unggas lebih cepat memproduksi telur kembali (Khajali et, al,2008).

\section{METODOLOGI PENELITIAN}

Penelitian ini dilaksanakan selama 2 bulan mulai dari bulan Mei sampai Juni 2016, bertempat di Kandang Unit Pembibitan Unggas Laboratorium Produksi Fakultas Peternakan, Universitas Halu Oleo, Kendari. Ayam yang digunakan dalam penelitian ini terdiri atas ayam ras petelur strain Lohman Brown sebanyak 18 ekor umur 60 - 70 minggu yang ditempatkan dalam kandang baterai sebanyak 18 petak. Pakan yang digunakan adalah pakan yang diformulasi sendiri yang tersusun atas $50 \%$ jagung $25 \%$ dedak, dan $25 \%$ konsentrat. Data yang diperoleh dianalis menggunakan analysis of variance (ANOVA) dan apabila terdapat perbedaan nyata $(\mathrm{P}<0,05)$ diantara perlakuan maka dilakukan uji lanjut dengan Uji Berganda Duncan (Steel and Torrie, 1991). 
Tabel 1. Metode 1(P0) Kombinasi Pembatasan Pakan dan Pemuasaan

\begin{tabular}{|c|c|c|}
\hline Hari ke & Makanan & Minuman \\
\hline 1 & Tidak diberi ransum basal & $\begin{array}{l}\text { Air minum di berikan hanya } \\
\text { dipagi hari }\end{array}$ \\
\hline 2 & Tidak diberi ransum basal & $\begin{array}{l}\text { Air minum di berikan hanya } \\
\text { dipagi hari }\end{array}$ \\
\hline 3 & $\begin{array}{l}\text { Diberikan } 25 \text { gr per ekor ransum } \\
\text { basal }\end{array}$ & Diberi air minum \\
\hline 4 & Tidak diberi ransum basal & $\begin{array}{l}\text { Air minum di berikan hanya } \\
\text { dipagi hari }\end{array}$ \\
\hline 5 & $\begin{array}{l}\text { Diberikan } 25 \text { gr per ekor ransum } \\
\text { basal }\end{array}$ & Diberi air minum \\
\hline $6-15$ & $\begin{array}{l}\text { Ransum diberikan secara selang } \\
\text { seling }\end{array}$ & $\begin{array}{l}\text { Air minum di berikan hanya } \\
\text { dipagi hari }\end{array}$ \\
\hline $16-30$ & Diberi ransum $100 \%$ & $\begin{array}{l}\text { Diberi air minum seperti } \\
\text { biasa }\end{array}$ \\
\hline
\end{tabular}

TabeL 2. Metode II (P1) Kombinasi Antara Pemuasaan dan Pemberian Daun Lamtoro Sebanyak 20\%

\begin{tabular}{|c|c|c|}
\hline Hari ke & Makanan & Minuman \\
\hline 1 & Tidak diberi ransum basal & $\begin{array}{l}\text { Air minum di berikan hanya } \\
\text { dipagi hari }\end{array}$ \\
\hline 2 & Tidak diberi ransum basal & $\begin{array}{l}\text { Air minum di berikan hanya } \\
\text { dipagi hari }\end{array}$ \\
\hline 3 & $\begin{array}{l}\text { Diberikan } 25 \text { gr per ekor yang } \\
\text { disubsitusikan } 20 \% \text { tepung daun } \\
\text { lamtoro }\end{array}$ & Diberi air minum \\
\hline 4 & Tidak diberi ransum basal & $\begin{array}{l}\text { Air minum di berikan hanya } \\
\text { dipagi hari }\end{array}$ \\
\hline 5 & $\begin{array}{l}\text { Diberikan } 25 \text { gr per ekor ekor } \\
\text { yang disubsitusika } 20 \% \text { tepung } \\
\text { daun lamtoro }\end{array}$ & Diberi air minum \\
\hline $6-15$ & $\begin{array}{l}\text { Diberikan } 30 \text { gr per ekor ekor } \\
\text { yang disubsitusika } 20 \% \text { tepung } \\
\text { daun lamtoro }\end{array}$ & $\begin{array}{l}\text { Air minum di berikan hanya } \\
\text { dipagi hari }\end{array}$ \\
\hline $16-30$ & Diberi ransum $100 \%$ & $\begin{array}{l}\text { Diberi air minum seperti } \\
\text { biasa }\end{array}$ \\
\hline
\end{tabular}


Tabel 3. Metode III (P2) Kombinasi Antara Pemuasaan dan Pemeberian Dedak.

\begin{tabular}{lll}
\hline Hari ke & \multicolumn{1}{c}{ Makanan } & \multicolumn{1}{c}{ Minuman } \\
\hline 1 & Tidak diberi ransum basal & $\begin{array}{l}\text { Air minum di berikan hanya } \\
\text { dipagi hari }\end{array}$ \\
2 & Tidak diberi ransum basal & $\begin{array}{l}\text { Air minum di berikan hanya } \\
\text { dipagi hari } \\
\text { Diberi air minum } \\
\text { Air minum di berikan hanya } \\
\text { dipagi hari }\end{array}$ \\
4 & $\begin{array}{l}\text { Diberikan 25 gr per ekor dedak } \\
\text { Tidak diberi ransum basal }\end{array}$ & $\begin{array}{l}\text { Diberi air minum } \\
5\end{array}$ \\
Diberikan 25 gr per ekor ekor & $\begin{array}{l}\text { Diberi air minum } \\
\text { dedak }\end{array}$ & $\begin{array}{l}\text { Diberi air minum seperti } \\
\text { biasa }\end{array}$ \\
\hline
\end{tabular}

\section{HASIL DAN PEMBAHASAN}

Rataan jenis bulu yang rontok pada ayam petelur afkir yang diberi metode force Molting yang berbed disajikan pada Tabel.4.

Tabel 4. Jumlah Bulu Rontok Ayam Petelur Afkir Yang Diberi Metode Force Molting Berbeda

\begin{tabular}{lccc}
\hline & \multicolumn{3}{c}{ Rata - rata Perlakuan } \\
\cline { 2 - 4 } \multicolumn{1}{c}{ Variabel } & PO & P1 & P2 \\
\hline Bulu Leher & $40,17^{\mathrm{a}}$ & $98,33^{\mathrm{b}}$ & $64,5^{\mathrm{b}}$ \\
Bulu punggung & 14,83 & 33,5 & 44,17 \\
Bulu Sayap & 6 & 11,17 & 6,5 \\
Bulu Ekor & 13,05 & 13,17 & 12,07 \\
Bulu Dada & $21,83^{\mathrm{a}}$ & $52,5^{\mathrm{b}}$ & $39,17^{\mathrm{b}}$ \\
\hline
\end{tabular}

Superskrip berbeda dalam baris yang sama menunjukkan perbedaan nyata pada taraf $5 \%$

\section{Bulu Leher}

Hasil analisis ragam terhadap pola rontok bulu pada bagian leher menunjukkan adanya perbedaan nyata $(\mathrm{P}<0,05)$. Rontok bulu tertinggi terjadi pada perlakuan dua (P1) dengan rata rata yang di peroleh adalah 98.33 helai, hal ini diduga pada perlakuan dua (P1) terdapat zat mimosin pada daun lamtoro yang dapat mempercepat proses perontokan bulu pada ayam petelur. Hal ini sesuai dengan pendapat Puyuh Jaya ( 2009) yang menyatakan bahwa efek yang merugikan dari mimosin yaitu menurunkan produksi telur dan merontokkan bulu unggas. 


\section{Bulu Punggung}

Hasil analisis ragam diketahui bahwa program force molting tidak memberikan pengaruh nyata $(\mathrm{P}>0,05)$ terhadap rontok bulu pada bagian punggung pada tubuh ayam. Rata - rata rontok bulu punggung pada $\mathrm{P} 0, \mathrm{P} 1$ dan $\mathrm{P} 2$ berturut turut adalah 14,83 helai, 33,5 helai dan 44,17 helai.

\section{Bulu Sayap}

Hasil analisis ragam diketahui bahwa program force molting tidak memberikan pengaruh nyata $(\mathrm{P}>0,05)$ terhadap rontok bulu pada bagian sayap pada tubuh ayam. Rata - rata rontok bulu sayap pada P0, P1 dan P2 berturut turut adalah 6 helai, 11,17 helai dan 6,5 helai.

\section{Bulu Ekor}

Hasil analisis ragam diketahui bahwa program force molting tidak memberikan pengaruh nyata $(\mathrm{P}>0,05)$ terhadap rontok bulu pada bagian sayap pada tubuh ayam. Rata - rata rontok bulu ekor pada P0, P1 dan P2 berturut turut adalah 13,05 helai, 13,17 helai dan 12,07 helai.

\section{Bulu Dada}

Hasil analisis ragam terhadap pola rontok bulu pada bagian dada menunjukkan adanya perbedaan nyata $(\mathrm{P}<0,05)$. Rontok bulu tertinggi terjadi pada perlakuan dua (P1) dengan rata - rata yang di peroleh adalah 52,5 helai, hal ini diduga pada perlakuan (P1) terdapat zat anti nutrisi pada daun lamtoro yaitu mimosin yang dapat mengikat zat lain pada pakan yang dikonsumsi sehingga ayam mengalami malnutrisi salah satunya adalah vitamin, sehingga ayam mengalami stres yang ditandai dengan perontokan bulu pada bagian ekor. Hal ini sesuai dengan pendapat Puchala et.al., (1996) menyatakan bahwa toksin mimosin menyebabkan defisiensi glysin untuk sintesis asam empedu, sehingga menyebabkan defisiensi vitamin yang larut dalam lemak.

\section{KESIMPULAN}

Berdasarkan hasil penelitian dapat disimpulkan bahwa: Perlakuan force moting berbeda pada ayam petelur afkir menunjukkan pengaruh nyata $(\mathrm{p}<0.05)$ pada jumlah rontok bulu leher dan bulu dada tetapi tidak berpengaruh nyata $(p>0.05)$ pada jumlah rontok bulu punggung, bulu sayap dan bulu ekor.

\section{DAFTAR PUSTAKA}

Anonim. 2012. Cara dan Proses Membuat Pupuk Organik Kompos dengan Bahan Kotoran Puyuh. http://puyuh jaya.wordpress. com. (5 agustus 2016).

Barua A, S.Furusawa, Y Yoshimura, T. Okamoto . 2001. Effects of force molting on $\mathrm{Ig} \mathrm{Y}$ concentration in egg yolk of chickens. Poult. Sci 38: 169174.

Berry, W.D. 2003. The Physiology of induced molting. Poult.Sci. 82:972-980. 
Esminger, M.E.1990. Feeds and nutrition. Poultry science $2^{\text {nd }}$ edition. Danville, Illinois: The Interstate Printers And Publisher. IUC.

Khajali, A. Raei, A. Aghei, D. Qujeg. 2008. Evaluation of a dietary organic selenium supplement at different dietary protein concentrations on growth performance, body composition and antioxidative status of broilers reared under heat stress. Asian-Aust. J. Anim. Sci. 23(4) : $501-507$

Kuenzel WJ. 2003. Neurobiology of molt in avian species. Poult. Sci 82: 981-991.

Puchala, R., JJ. Davis, T. Sahlu., (1996). Biomedical sciences and application. Journal of Chromatography B. 68(2): 375-378.

Razak. A, 2010. Hubungan penurunan berat badan dengan peningkatan produksi ayam petelur (dekalb warren) dalam program cekaman luruh bulu. Poult . Sci . 39 (1) $1-22$.
Sitanggang. 2005. Panduan Lengkap Beternak Itik. Agromedia Pustaka. Jakarta

Steel, R.G.D., and J.H. Torrie, 1995. Prinsip dan prosedur statistik. Terjemahan: B. Sumantri. PT. Gramedi Pustka Utama, Jakarta.

Suprijatna H.T, Astuti dan S.S Maryuni. 2005. Manajemen Ternak Unggas. Penebar Swadaya. Jakarta

Walbert, D . 2004 . Raising ducks. University of North Caroline, Cappel Hill, USA. 